\title{
Mass Spectrometric and Synchrotron Radiation based techniques for the identification and distribution of painting materials in samples from paints of Josep Maria Sert
}

\author{
Anna Lluveras-Tenorio ${ }^{1 *}$, Alessia Andreotti ${ }^{2}$, llaria Bonaduce ${ }^{2}$, Sarah Boularand ${ }^{1}$, Marine Cotte ${ }^{3,4}$, Josep Roqué ${ }^{5}$, \\ Maria Perla Colombini ${ }^{2}$ and Marius Vendrell-Saz ${ }^{1}$
}

\begin{abstract}
Background: Establishing the distribution of materials in paintings and that of their degradation products by imaging techniques is fundamental to understand the painting technique and can improve our knowledge on the conservation status of the painting. The combined use of chromatographic-mass spectrometric techniques, such as GC/MS or Py/GC/MS, and the chemical mapping of functional groups by imaging SR FTIR in transmission mode on thin sections and SR XRD line scans will be presented as a suitable approach to have a detailed characterisation of the materials in a paint sample, assuring their localisation in the sample build-up. This analytical approach has been used to study samples from Catalan paintings by Josep Maria Sert y Badía (20 ${ }^{\text {th }}$ century), a muralist achieving international recognition whose canvases adorned international buildings.

Results: The pigments used by the painter as well as the organic materials used as binders and varnishes could be identified by means of conventional techniques. The distribution of these materials by means of Synchrotron Radiation based techniques allowed to establish the mixtures used by the painter depending on the purpose.

Conclusions: Results show the suitability of the combined use of SR $\mu$ FTIR and SR $\mu$ XRD mapping and conventional techniques to unequivocally identify all the materials present in the sample and their localization in the sample build-up. This kind of approach becomes indispensable to solve the challenge of micro heterogeneous samples. The complementary interpretation of the data obtained with all the different techniques allowed the characterization of both organic and inorganic materials in the samples layer by layer as well as to establish the painting techniques used by Sert in the works-of-art under study.
\end{abstract}

Keywords: GC/MS, Mapping, FTIR, Synchrotron radiation, XRD, Paintings

\section{Background}

Paintings are complex systems due to the fact that they are multi-material, multi-layered. The painting technique is thus determined not only by the knowledge of which materials constitute a work of art but also by determining their distribution, layer by layer.

The use of conventional techniques, namely optical $(\mathrm{OM})$, scanning electron microscopy coupled with

\footnotetext{
*Correspondence: Iluveras@for.unipi.it

'Departament de Cristal.lografia, Mineralogia I Dipòsits Minerals, University of Barcelona, C/Marti i Franquès S/N, 08015 Barcelona Spain

Full list of author information is available at the end of the article
}

Electron Dispersive Spectroscopy (SEM-EDS), micro Fourier Transform Infrared Spectroscopy ( $\mu$ FTIR), Raman spectroscopy, Gas Chromatography/Mass Spectrometry (GC/MS) and Pyrolysis/Gas Chromatrography/Mass spectrometry $(\mathrm{Py} / \mathrm{GC} / \mathrm{MS})$ can provide a detailed and almost complete characterization of the materials present in a painting.

However a complete analysis of the painting requires both in plane and in depth information and an imaging of organic and inorganic materials of the paint cross sections is fundamental for an in depth characterization of painting systems, allowing the elemental and molecular 
heterogeneities to be resolved both within and between layers [1-4].

In this paper a multi-analytical approach for the characterization of organic and inorganic materials in paint micro samples is shown. OM and SEM-EDS were used for the morphological characterization of the samples. Conventional Fourier Transform Infrared Spectroscopy (FTIR), analytical Pyrolisis in the presence of hexamethyldisilazane coupled on line with gas chromatography/mass spectrometry analysis (Py/GC/ MS) [1,5] as well as a GC/MS analytical procedure for the identification of lipids, waxes, proteins, and resinous materials in the same microsample was then used for the identification of organic materials and their degradation products in the bulk sample [6] were used to characterize the materials (organic and some inorganic) in the bulk of the samples. Finally, Synchrotron Radiation (SR) micro FTIR in transmission mode allowed the establishment of the chemical images of the functional groups in a thin section highlighting the distribution of these materials both in depth and along the sample [7-13]. Transmission has been chosen due to its higher spectra quality, easier interpretation and wider database. To complement the characterization of pigments, dryers and fillers, Synchrotron Radiation micro X-Ray Diffraction (SR XRD) line scans in transmission mode was used to establish the crystalline phases present $[14,15]$.

This work describes the results obtained by the application of the above mentioned multi- analytical approach to three samples from Josep Maria Sert's paintings in order to establish the painting technique used by the painter. Josep Maria Sert i Badia (18761945) was one of the most famous Catalan muralists of the beginning of the $20^{\text {th }}$ achieving international recognition. His big size canvases adorned the walls of such buildings as the assembly hall of the League of Nations (Geneva), the RCA Building in Rockefeller Centre and the Waldorf-Astoria Hotel (both in New York City). Sert's painting technique is of particular interest because the painter's work changed from polychrome and decorative mural paintings in his former works to almost monochrome paintings (sepia, gilded and silvery tonalities). In the occasion of the publication of a book on Sert paintings in the city of Vic (Barcelona) some of his paintings have been studied [16]. A total of seven samples were collected from six canvases painted between 1906-1945. Sampled canvases were the "Fight Between Jacob and the Angel" (1906), the winter and spring panels of "The Fourth Seasons" (1917-1920), "Heliodor Expelled from the Temple" (1920) and the central panel of the painting "Crucifixion" (1945).

On the basis of the results obtained on the preliminary analyses of the seven samples by SEM-EDS, FTIR and
Py/GC/MS (the whole body of data are provided as supplementary information) it was decided to proceed with SR $\mu$ FTIR mapping and SR $\mu$ XRD linear scan on three samples that were representative of the two different painting techniques used by the painter. This paper presents the results obtained for the three chosen samples, and discusses the data in order to reconstruct the painting technique.

\section{Experimental section \\ Reagents}

For the chromatographic technique all the solvents used were Baker HPLC grade. Hexadecane, tridecanoic acid and norleucine, used as internal standards, hexamethyldisilazane (HMDS), and N,O-bis(trimethylsilyl)trifluoroacetamide (BSTFA) containing 1\% trimethylchlorosilane were purchased from Sigma (Milan, Italy). N-tert-Butyldimethylsilyl- $N$-methyltrifluoroacetamide (MTBSTFA) with $1 \%$ trimethylchlorosilane was from Fluka (USA). All reagents and chemicals were used without any further purification. Standard solutions of amino acids in hydrochloric acid $(0.1 \mathrm{M})$, containing $12.5 \mu \mathrm{mol} / \mathrm{mL}$ of proline and hydroxyproline, $1.25 \mu \mathrm{mol} / \mathrm{mL}$ of cysteine and $2.5 \mu \mathrm{mol} / \mathrm{mL}$ of aspartic acid, glutamic acid, alanine, arginine, phenylalanine, glycine, hydroxylysine, isoleucine, histidine, leucine, lysine, methionine, serine, tyrosine, threonine, and valine was purchased from Sigma-Aldrich (USA). A solution containing lauric acid, suberic acid, azelaic acid, myristic acid, sebacic acid, palmitic acid, oleic acid, stearic acid (all purchased from Sigma-Aldrich, USA) in the range of 2-3 $\mu / \mathrm{g}$ was prepared in isooctane and stored at $4^{\circ} \mathrm{C}$.

A polyester resin polymerised by a peroxy organic hardener (Cronolite E.I, Plastiform, Spain) was used for the cross-section preparation. The epoxy resin used for the SR FTIR slices was purchased at Plastiform, Spain.

\section{Apparatus and analytical procedure}

- Stereo microscope Nikon SMZ 1500 (Izasa S.A., Barcelona, Spain)

- Nikon Eclipse LV 100 PDL polarizing microscope equipped with a Nikon Digital Camera DMX 1200 F (Izasa S.A., Barcelona, Spain).

- Scanning Electron Microscope (SEM) JEOL (Tokyo, Japan) JSM-840 (secondary and backscattered electron detection) coupled with an Energy Dispersive X-ray Spectroscopy (EDS) facility LINK AN 10000 microanalyser. The acceleration voltage used was $20 \mathrm{keV}$. EDS mappings were collected by using a Cambridge Leica Stereoscan S-360 coupled with INCA Energy Sèrie 200 microanalyser (Oxford Instruments). Conditions were as follow: filament 2,8 A, probe $3 \mathrm{nA}$ and EHT $20 \mathrm{kV}$. 
Table 1 Description of the paint samples

\begin{tabular}{llll}
\hline Sample name & Painting & Year & Sampling area \\
\hline VIC 2 & "Heliodor Expelled from the Temple" & 1920 & Black line next to a red one \\
\hline VIC 5 & "Fight Between Jacob and the Angel" & 1906 & green colour \\
\hline VIC 7 & "In Honor of the East" & 1926 & Gilded area \\
\hline
\end{tabular}

- Bomem MB-120 Fourier Transform Infrared Spectrometer equipped with a DTGS detector. The spectra are the sum of 30 scans collected from 4000 to $350 \mathrm{~cm}^{-1}$ at a resolution of $4 \mathrm{~cm}^{-1}$ when working with the diamond cell.

- Bomem MB-120 Fourier Transform Infrared Spectrometer, equipped with a Spectra-Tech Analytical Plan microscope, was used with the diamond cell, as a sample holder. The spectrometer has a KBr beamsplitter and a Globar source. The microscope has its own mercury cadmium telluride (MCT) detector refrigerated with liquid nitrogen. Spectrum was recorded between 4000 and $720 \mathrm{~cm}^{-1}$ with a resolution of $4 \mathrm{~cm}^{-1}$ and an accumulation of 100 scans.
- Pyroprobe CDS Analytical Inc. 5000 Series (Oxford, USA). It was operating with an initial temperature of $50^{\circ} \mathrm{C}$, up to $550^{\circ} \mathrm{C}$ at $20^{\circ} \mathrm{C} / \mathrm{ms}$, then isothermal for $20 \mathrm{sec}$. (probe run time $0.33 \mathrm{~min}$ ). The pyrolyser was coupled on-line with the injection port of a 6890 N GC System Gas Chromatograph (Agilent Technologies, Palo Alto, CA, USA), coupled with a 5973 Mass Selective Detector (Agilent Technologies, Palo Alto, CA, USA) single quadrupole mass spectrometer, equipped with split/splitless injector. The interface Py/GC temperature was $180^{\circ} \mathrm{C}$, the transfer line $300^{\circ} \mathrm{C}$, the valve oven $290^{\circ} \mathrm{C}$. The mass spectrometer was operating in the electron impact (EI) positive mode $(70 \mathrm{eV})$.
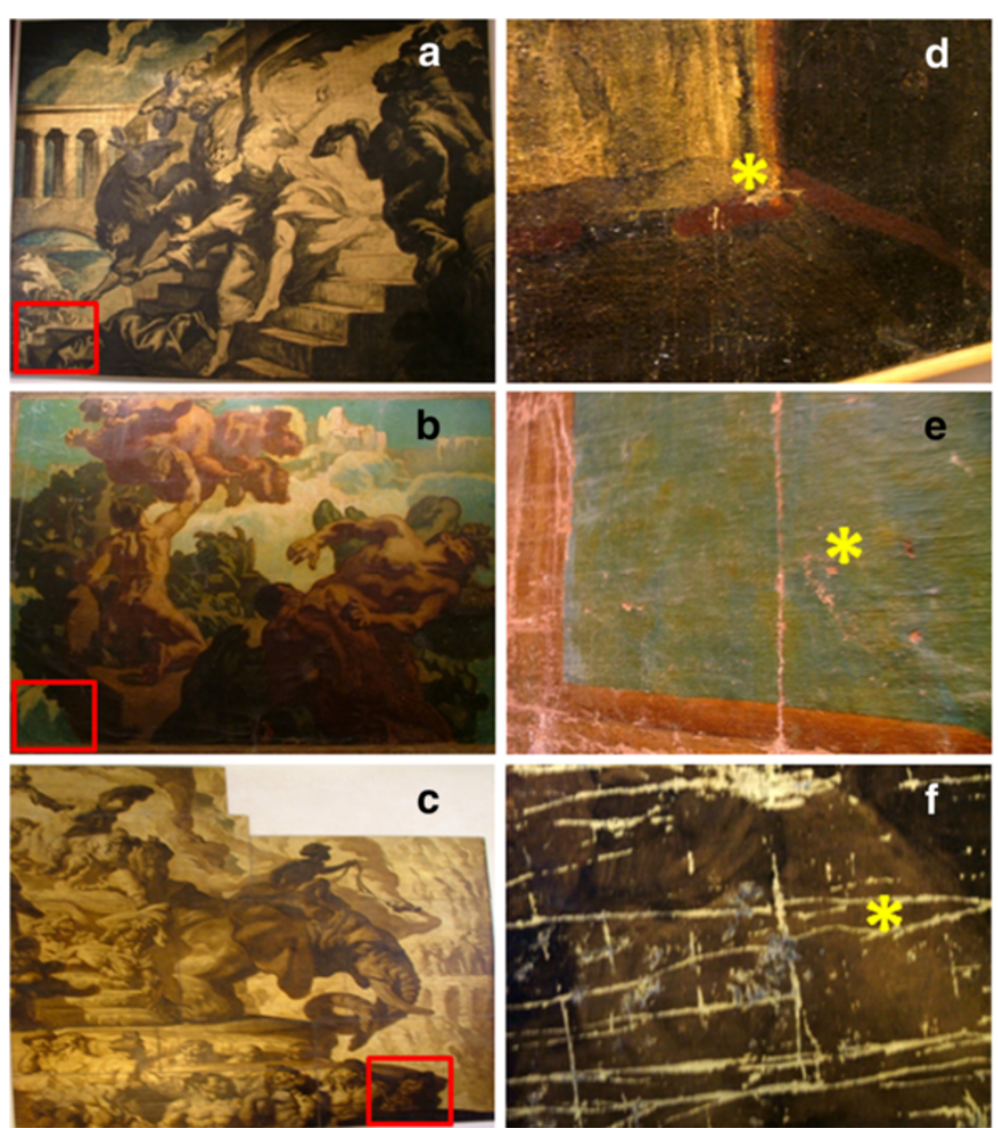

Figure 1 Sampled canvases: a) "Heliodor Expelled from the Temple", b) "Fight Between Jacob and the Angel", c) "In Honor of the East"; the square evidences the area sampled showed in d), e) and f), respectively. The * marks the specific sampling point corresponding to samples VIC 2 (d), VIC 5(e) and VIC 7(f). 

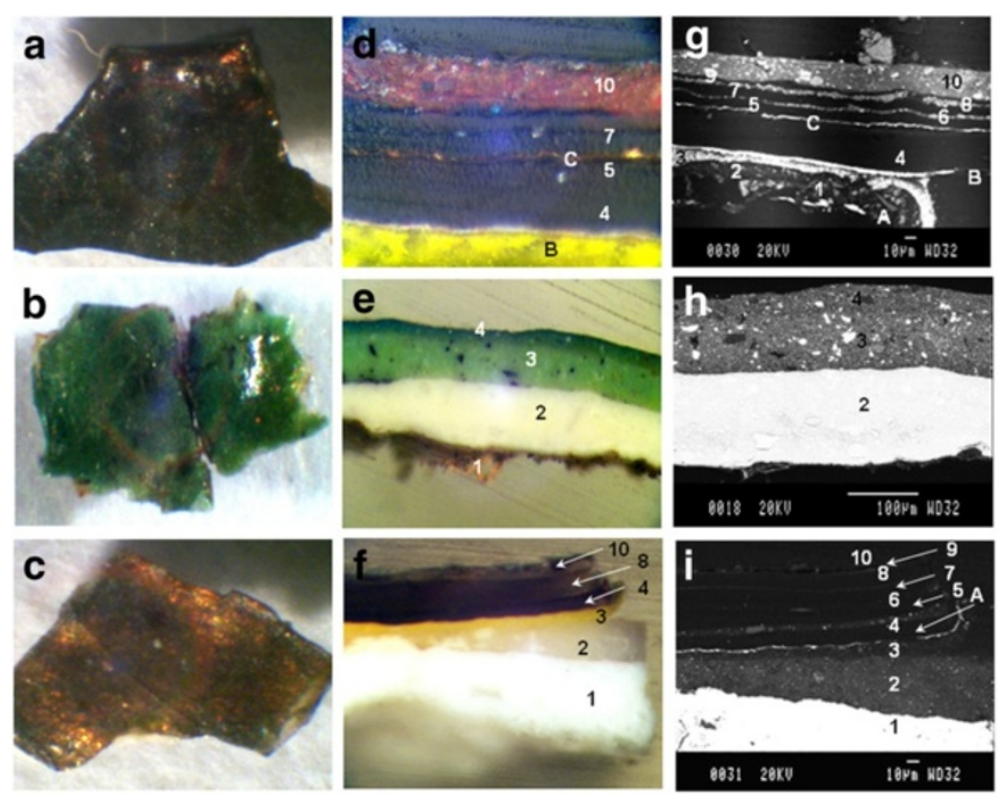

Figure 2 Stereomicroscope images of the surfaces of samples a) VIC 2; b) VIC 5 and c) VIC 7; Optical microscopic image of the polished cross-section d) VIC 2; e) VIC 5; f) VIC 7; scanning electron microscope images of the cross-section g) VIC 2; h) VIC 5; i) VIC 7. Paint layers are indicated with numbers while metallic layers are indicated with $A, B, C$.

A few $\mu \mathrm{g}$ of the samples admixed with $2 \mu \mathrm{l}$ of hexamethyldisilazane were inserted into a quartz tube. Detailed working conditions are published elsewhere [17].

- A 6890 N GC System Gas Chromatograph (Agilent Technologies, Palo Alto, CA, USA), coupled with a 5975 Mass Selective Detector (Agilent Technologies, Palo Alto, CA, USA) single quadrupole mass spectrometer, equipped with a PTV injector was used. The mass spectrometer was operating in the electron impact (EI) positive mode $(70 \mathrm{eV})$. The MS transfer line temperature was $280^{\circ} \mathrm{C}$; the $\mathrm{MS}$ ion source temperature was kept at $230^{\circ} \mathrm{C}$; and the MS quadrupole temperature was at $180^{\circ} \mathrm{C}$. This instrument was used for the analysis of samples processed with the combined analytical procedure for the simultaneous identification of glycerolipids, proteinaceous materials, plant and animal resins, and natural waxes in the same micro sample. The procedure is based on a sample multi step chemical pre-treatment (solvent extractions and microwaveassisted chemolysis) that is able to separate the various organic components into three different fractions: amino acid, acidic and neutral fractions. The detailed operating conditions, and the analytical procedure are published elsewhere [6].

- Microwave oven model MLS-1200 MEGA Milestone (FKV, Sorisole (BG,) Italy). Acidic hydrolysis conditions were : power $250 \mathrm{~W}$ for $10 \mathrm{~min}$; power $500 \mathrm{~W}$ for $30 \mathrm{~min}$ in the vapor phase with $30 \mathrm{~mL}$ of $6 \mathrm{~N} \mathrm{HCl}$ at $160^{\circ} \mathrm{C}$ for $40 \mathrm{~min}$. Saponification conditions were: power $200 \mathrm{~W}$ with $300 \mu \mathrm{L}$ of $\mathrm{KOH}_{\mathrm{ETOH}} 10 \%$ wt at $80^{\circ} \mathrm{C}$ for $60 \mathrm{~min}$ [6].

- Synchrotron radiation Fourier transform infrared microspectroscopy (SR FTIR) in transmision mode was performed at the end-station ID21 at the European Radiation Synchrotron Facility (ESRF, Grenoble, France). The microscope is a Continu $\mu \mathrm{m}$ (Thermo) coupled with a Nexus Spectrometer (Thermo). The detector is a $50 \mu \mathrm{m}$ MCT. Maps were recorded using 4 microns step and 40 scans for each spectrum. Beam spot and resolution were fixed at $8 \times 8 \mu \mathrm{m}^{2}$ and $8 \mathrm{~cm}^{-1}$, respectively. In all cases the aperture and the step size chosen generate

Table 2 Summary of the morphological characterization of the samples

\begin{tabular}{|c|c|c|c|c|c|c|c|}
\hline Sample & $\begin{array}{l}\text { Appearance of } \\
\text { the surface }\end{array}$ & $\begin{array}{l}\text { Total number } \\
\text { of layers }\end{array}$ & $\begin{array}{l}\text { Thickness } \\
(\min -\max / \mu \mathrm{m})\end{array}$ & $\begin{array}{l}\text { Number of highly } \\
\text { pigmented layers }\end{array}$ & $\begin{array}{l}\text { Number of mainly } \\
\text { organic layers }\end{array}$ & $\begin{array}{c}\text { Number of } \\
\text { metallic layers }\end{array}$ & $\begin{array}{l}\text { Metallic } \\
\text { leaves }\end{array}$ \\
\hline VIC 2 & Dark red & 13 & $2-20$ & 6 & 4 & 3 & $\mathrm{AuCu}-\mathrm{Zn}$ \\
\hline VIC 5 & Green & 4 & $25-100$ & 4 & 0 & 0 & - \\
\hline VIC 7 & golden & 11 & $1-100$ & 6 & 4 & 1 & $\mathrm{Au}$ \\
\hline
\end{tabular}


Table 3 Results of the different techniques for VIC 2, VIC 5 and VIC 7 and inorganic compounds identified

\begin{tabular}{|c|c|c|c|c|c|}
\hline Sample & Layer number & EDS results & FTIR bands & $\begin{array}{l}\text { XRD crystalline } \\
\text { phases }\end{array}$ & $\begin{array}{l}\text { Inorganic compounds } \\
\text { identified }\end{array}$ \\
\hline \multirow[t]{13}{*}{ VIC 2} & 10 & $\begin{array}{c}\mathrm{Al}, \mathrm{S}, \mathrm{Si}, \mathrm{P}, \mathrm{Ca} \\
\mathrm{Cr}, \mathrm{Ba}, \mathrm{Na}, \mathrm{Fe}\end{array}$ & $\begin{array}{c}550,456 \\
1420,876 \\
1586 \\
1318 \\
743,723\end{array}$ & - & $\begin{array}{c}\text { Iron oxide } \\
\text { calcite } \\
\text { zinc compound } \\
\text { calcium oxalates } \\
\text { Quartz }\end{array}$ \\
\hline & 9 & $\begin{array}{l}\mathrm{S}, \mathrm{Al}, \mathrm{P}, \mathrm{Ca}, \mathrm{Si} \\
\mathrm{Na}, \mathrm{K}>\mathrm{Zn}, \mathrm{Fe}\end{array}$ & $\begin{array}{l}2012 \\
2092\end{array}$ & & $\begin{array}{c}\text { Bone black } \\
\text { Prussian blue }\end{array}$ \\
\hline & 8 & $\mathrm{Cl}$ & - & & - \\
\hline & 7 & $\mathrm{Cl}$ & - & & - \\
\hline & 6 & $\begin{array}{l}\mathrm{Al}, \mathrm{S}, \mathrm{Si}, \mathrm{P}, \mathrm{Ca} \\
\mathrm{Cr}, \mathrm{Ba}, \mathrm{Na}>\mathrm{Fe}\end{array}$ & & & - \\
\hline & 5 & $\mathrm{Cl}$ & & & \\
\hline & $A$ & $\mathrm{Au}>>>\mathrm{Ag}, \mathrm{Cu}$ & & & Gold \\
\hline & 4 & $\mathrm{Cl}$ & & & - \\
\hline & $B$ & $\mathrm{Cu}, \mathrm{Zn}$ & & & brass \\
\hline & 3 & $\mathrm{~Pb}, \mathrm{Cr}, \mathrm{Ba}$ & $1170,1112,1072,984$ & & Barium sulphate \\
\hline & 2 & $\mathrm{~S}, \mathrm{Ba}, \mathrm{Pb}, \mathrm{Cr}$ & $\begin{array}{c}635,608 \\
873,820\end{array}$ & & $\begin{array}{l}\text { Lead chrome yellow } \\
\left(\mathrm{PbCrO}_{4}\right)\end{array}$ \\
\hline & 1 & $\mathrm{Fe}, \mathrm{Mn}, \mathrm{Pb}$ & & & $\begin{array}{c}\text { Clay? } \\
\text { Iron oxide? }\end{array}$ \\
\hline & C & $\mathrm{Cu}, \mathrm{Zn}$ & & & brass \\
\hline \multirow[t]{4}{*}{ VIC 5} & 4 & $\mathrm{Sr}, \mathrm{Pb}, \mathrm{Zn}, \mathrm{Cr}$ & $923,909,842$ & - & Strontium yellow \\
\hline & 3 & $\mathrm{Cd}, \mathrm{Fe}, \mathrm{Al}, \mathrm{Si}$ & $\begin{array}{c}2092 \\
1400,680 \\
3698,3636,1030 \\
1008,916 \\
1585\end{array}$ & & $\begin{array}{l}\text { Prussian blue } \\
\text { Lead white } \\
\text { Kaolinite } \\
\text { Zinc compound }\end{array}$ \\
\hline & 2 & $\mathrm{~Pb}$ & $3538,1400,1047$ & & Lead white \\
\hline & 1 & - & - & & - \\
\hline \multirow[t]{11}{*}{ VIC 7} & 10 & $\mathrm{Cl}$ & & - & \\
\hline & 9 & $\mathrm{Ca}$ & 2012 & apatite & Bone black \\
\hline & 8 & $\mathrm{Cl}$ & - & - & - \\
\hline & 7 & - & - & - & - \\
\hline & 6 & $\mathrm{Cl}$ & - & - & - \\
\hline & 5 & $\begin{array}{c}\mathrm{P}, \mathrm{Ca}, \mathrm{Na}, \mathrm{Al}, \mathrm{Si}, \\
\mathrm{Mg}\end{array}$ & - & $\begin{array}{c}\text { Apatite } \\
\text { Hydroxyapatite } \\
\text { barite }\end{array}$ & Bone black \\
\hline & 4 & $\mathrm{Cl}$ & - & - & - \\
\hline & A & $\mathrm{Au}$ & - & $\begin{array}{c}\text { Crocoite, } \\
\text { Au }\end{array}$ & $\begin{array}{c}\text { Chrome yellow } \\
\text { Gold }\end{array}$ \\
\hline & 3 & $\mathrm{Zn}, \mathrm{P}, \mathrm{Ca}, \mathrm{Pb}$ & $3532,1400,837$ & $\begin{array}{c}\text { cerussite } \\
\text { hydrocerussite; } \\
\text { Zinc oxide; } \\
\text { mirabilite }\end{array}$ & $\begin{array}{l}\text { Lead white } \\
\text { Zinc white }\end{array}$ \\
\hline & 2 & $\mathrm{Zn}$ & - & Zinc oxide; & Zinc white \\
\hline & 1 & $\mathrm{~Pb}, \mathrm{Zn}$ & $\begin{array}{c}3532,1420,1052 \\
837 \\
1524\end{array}$ & $\begin{array}{c}\text { Cerussite } \\
\text { hydrocerussite } \\
\text { Lead acetate }\end{array}$ & $\begin{array}{l}\text { Lead white } \\
\text { Lead acetate }\end{array}$ \\
\hline
\end{tabular}

overlapping areas in order to increase the resolution of the components [18].

- Microtome Ultracut E with a tungsten knife for slices of less than $12 \mu \mathrm{m}$ was used.
- SR XRD (Synchrotron radiation X Ray diffraction) patterns in transmission mode were acquired at the beamline ID18F of the ESRF. A focal spot of 2,3 $\mu \mathrm{m}$ in the vertical direction and $11 \mu \mathrm{m}$ in the horizontal 

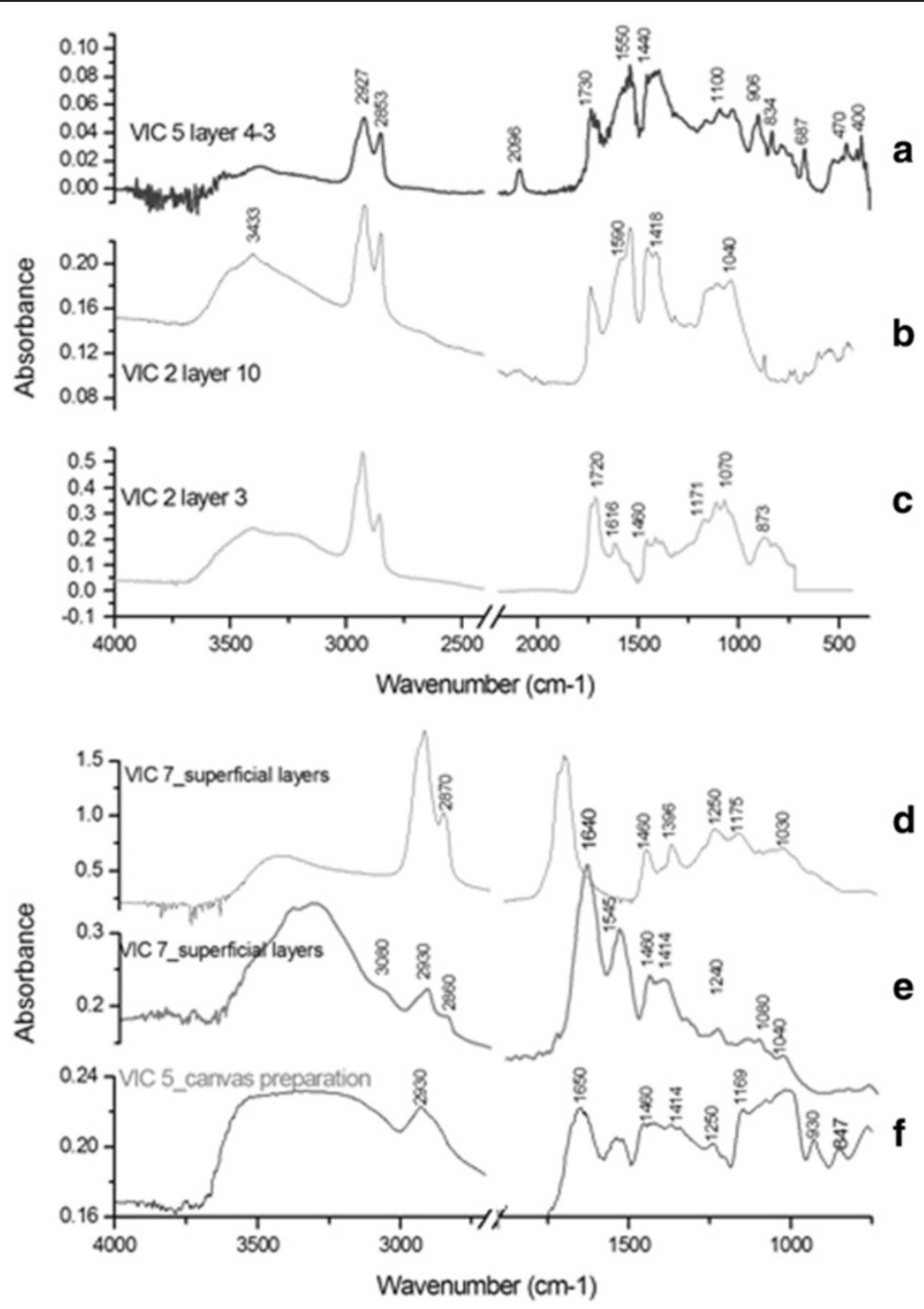

Figure 3 Conventional FTIR spectra of some of the samples: a) b) and c) representative spectra of pigment layers where oil is detected as binding media; d) natural resin features, e) proteinaceous material bands and f) polysaccharide material. Spectra have been recorded in transmission mode at a resolution of $4 \mathrm{~cm}^{-1}$. VIC 5 and VIC 2 layer 10 are the sum of 30 scans collected from 4000 to $350 \mathrm{~cm}^{-1}$ while the rest of the spectra are the sum of 100 scans collected from 4000 to $720 \mathrm{~cm}^{-1}$.

direction was chosen with steps of $2 \mu \mathrm{m}$ in the vertical direction. A wavelength of $0,443 \AA$ ( $28 \mathrm{keV})$ was selected and the acquisition time was 20 seconds per pattern. The diffraction signal was recorded in transmission by means of a 2 dimensional CCD-based X-ray detector. The crosssection was placed into the focused beam with the paint layers oriented horizontally. The sample preparation for transmission XRD experiments has been already reported in previous works. It consists in an embedding of the fragment in polyester resin polymerised by a peroxo organic hardener under low humidity conditions and sectioned with a diamond saw of thickness $0,1 \mathrm{~mm}$ into a 200 microns thick slice $[13,19]$. Patterns were fitted with the ESRF FIT2D package software [20].

\section{Samples}

The samples chosen for the application of the multi analytical approach, the canvases of provenience and the sampling point description are summarized in Table 1. A picture of the sampled canvases is presented in Figure 1. Samples were always taken from nicks of the canvases trying to minimize the damage to the paintings. The selection was made in order to represent the different techniques applied by Sert, from his classical and standard oil paintings (sample VIC 5) to the multilayered metallic application with interposed varnishes and colored layers (samples VIC 2 and VIC 7). 
Table 4 FTIR results for the paint samples

\begin{tabular}{|c|c|c|c|c|c|c|}
\hline Sample & Layer & $\begin{array}{l}\text { Lipid } \\
\text { material }\end{array}$ & $\begin{array}{l}\text { Natural } \\
\text { resin }\end{array}$ & $\begin{array}{c}\text { Proteinaceous } \\
\text { material }\end{array}$ & $\begin{array}{l}\text { Polysaccharide } \\
\text { materials }\end{array}$ & Inorganic materials \\
\hline \multirow[t]{2}{*}{ VIC 2} & $\begin{array}{l}\text { Superficial } \\
\text { layers }\end{array}$ & + & + & - & - & $\begin{array}{c}\text { Calcite }\left(\mathrm{CaCO}_{3}\right) \\
\text { Iron oxide } \\
\text { Calcium oxalates }\left(\mathrm{CaC}_{2} \mathrm{O}_{4}\right) \\
\text { Quartz }\left(\mathrm{SiO}_{2}\right)\end{array}$ \\
\hline & $\begin{array}{l}\text { Under } \\
\text { metallic } \\
\text { leave }\end{array}$ & + & & - & - & $\begin{array}{l}\text { Barium sulphate }\left(\mathrm{BaSO}_{4}\right) \\
\text { Chrome yellow }\left(\mathrm{PbCrO}_{4}\right) \\
\text { Metal Carboxylates }\end{array}$ \\
\hline \multirow[t]{3}{*}{ VIC 5} & $\begin{array}{l}\text { Pigment } \\
\text { layers on top }\end{array}$ & + & - & - & - & $\begin{array}{c}\text { strontium yellow }\left(\mathrm{SrCrO}_{4}\right) \\
\text { Prussian blue }\left(\mathrm{Fe}\left[\mathrm{Fe}\left(\mathrm{CN}_{6}\right]_{3}\right)\right. \\
\text { Clay (kaolinite) } \\
\text { Lead white }\left(2 \mathrm{PbCO}_{3} \cdot \mathrm{Pb}(\mathrm{OH})_{2}\right) \\
\text { Calcium oxalates }\left(\mathrm{CaC}_{2} \mathrm{O}_{4}\right) \\
\text { Metal Carboxylates }\end{array}$ \\
\hline & Preparation & + & - & - & - & Lead white $\left(2 \mathrm{PbCO}_{3} \cdot \mathrm{Pb}(\mathrm{OH})_{2}\right)$ \\
\hline & Canvas prep & - & - & - & + & - \\
\hline \multirow[t]{3}{*}{ VIC 7} & $\begin{array}{l}\text { Superficial } \\
\text { layers }\end{array}$ & - & + & + & - & - \\
\hline & Mordent & + & - & - & - & $\begin{array}{l}\text { Chrome yellow }\left(\mathrm{PbCrO}_{4}\right) \\
\text { Barium sulfate }\left(\mathrm{BaSO}_{4}\right)\end{array}$ \\
\hline & Preparation & + & - & - & - & Lead white $\left(2 \mathrm{PbCO}_{3} \cdot \mathrm{Pb}(\mathrm{OH})_{2}\right)$ \\
\hline
\end{tabular}

\section{Results and discussion}

\section{Morphological characterisation}

Figure 2 shows the stereomicroscope images of the samples surface and the optical and electron microscope images of their cross-sections. Table 2 summarizes the results of the morphological characterization of the samples. The composition of the metallic layers obtained with the EDS is reported as well, while the elemental composition of the other layers is summarized in Table 3. Table 3 summarizes the inorganic compounds identified and their distribution in the sample layers with the different techniques discussed below.

The morphological characterization of the samples evidenced the differences of the two pictorial techniques identified: two different kinds of stratigraphies and superficial appearances. In particular a first group, represented by sample VIC 5, presented few pictorial layers (mainly a preparation layer together with one or a couple of pigmented layers) with a colored superficial appearance. The second group is represented by samples VIC 2 and 7, which present a dark surface with hints of golden shiny reflects. Their stratigraphies show several layers (more than 10) amongst which there are always at least a metallic layer and an alternation of pigmented and unpigmented layers. It is interesting to notice how thin some of the layers are $(1-2 \mu \mathrm{m})$.

\section{Fourier transformed infrared spectroscopy}

Figure 3 shows some spectra representative of the materials identified in the samples VIC 2, VIC 5 and VIC 7. In order to obtain information on the distribution of both organic and inorganic materials, layers were selectively sampled (when possible) using tungsten needles [21] under the stereomicroscope. The identification of the different materials in the sample spectra was made by comparison with reference data [19,22-30].

An oil medium can be identified in the spectra by the presence of the characteristic $\mathrm{CH}$ stretching and carbonyl $(\mathrm{C}=\mathrm{O})$ stretching bands in Figure $3 \mathrm{a}, \mathrm{b}$ and $\mathrm{c}$ in the regions, $3000-2800 \mathrm{~cm}^{-1}$ and $1750-1650 \mathrm{~cm}^{-1}$, respectively $[19,23]$. In almost all cases the formation of metal carboxylates could be observed in the region $1650-1500 \mathrm{~cm}^{-1}$ [30]. In the pigmented layers (Figure 3 a,b), carbonyl vibrations are observed at around $1740 \mathrm{~cm}^{-1}$ due to esters and the band intensity is lower than that of the metal carboxylate band. This indicates

Table 5 Summary of results from the Py/GC/MS analysis

\begin{tabular}{lccccc}
\hline Sample & Drying oil & Pinaceae resin & Shellac & Saccharide material & Proteinaceous material \\
\hline VIC 2 & + & + & + & + & - \\
\hline VIC 5 & + & - & - & + & $+($ egg) \\
\hline VIC 7 & + & + & + & + & - \\
\hline
\end{tabular}




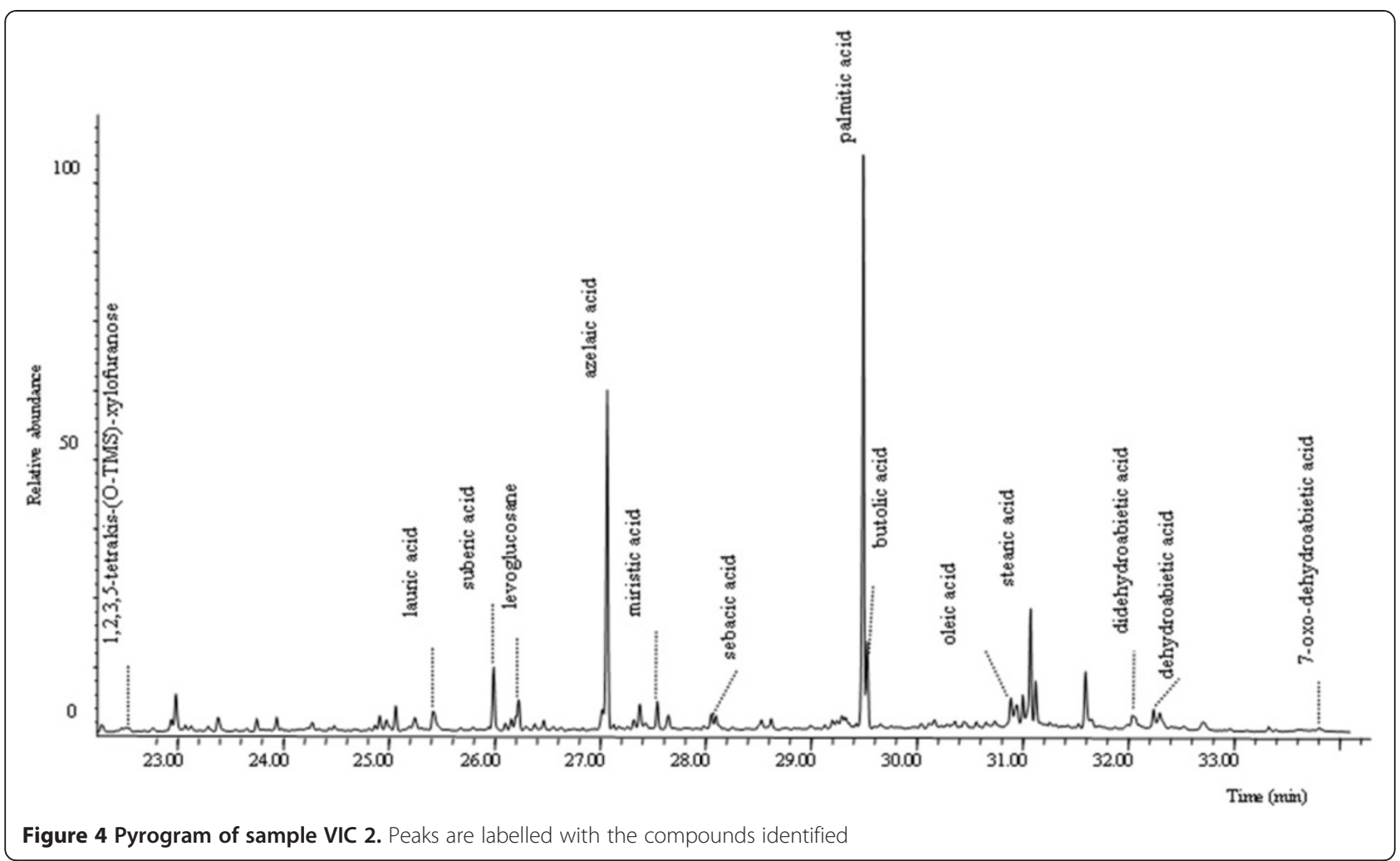

the hydrolysis of the triglycerides and the reaction of the carboxylic acids to metal carboxylates. On the contrary, in the organic layers underneath the metallic leaves(mordant layers) (Figure 3c) the band around $1715 \mathrm{~cm}^{-1}$ corresponds to the carboxylic acid moieties [30]. The presence of different kind of pigments and the pigment concentration in the layer, the different coordination states of the carboxylic acid around the metal atom or the nature of the carboxylic acid justify the variations in the frequencies observed for the carboxylates [23,30].

Bands corresponding to inorganic materials (Table 3) such as prussian blue $\left(2092 \mathrm{~cm}^{-1}\right)$, lead white (3533, 1410, 1047, $683 \mathrm{~cm}^{-1}$ ) and strontium yellow (923, 909, $\left.842 \mathrm{~cm}^{-1}\right)$, calcium oxalates (1640. 1318, $\left.790 \mathrm{~cm}^{-1}\right)$, quartz $\left(743,723 \mathrm{~cm}^{-1}\right)$ and iron oxides $\left(550,456 \mathrm{~cm}^{-1}\right)$, chrome yellow $\left(820,870 \mathrm{~cm}^{-1}\right)$ and barium sulphate $\left(1150,1117,1085,635,610 \mathrm{~cm}^{-1}\right)$ can also be easily identified in the spectra shown in Figure 3a, 3b and 3c.
Finally, the spectrum presented in Figure 3d resembles that of a natural resin while the ones presented in Figure $3 e$ and $f$ present the characteristic features of a proteinaceous and polysaccharide material detected in VIC 7 and VIC 5, respectively.

Table 4 summarizes all the data obtained for samples VIC 2, VIC 5 and VIC 7 indicating the position of the compounds in the sample layers when possible.

\section{Pyrolysis/gas chromatography/mass spectrometry}

The organic materials contained in the multi layered samples are summarized in Table 5, and particularly, it could be assessed that:

- samples VIC 2 and 7 (Figure 4 shows the pyrograms of the sample VIC 2) are characterised by the presence of monocarboxylic acids and a relatively high content of dicarboxilic acids attributable to a siccative oil [5]. Dehydroabietic acid together with didehydroabietic and 7-oxo dehydroabietic acid are markers of a Pinaceae

Table 6 Amino acidic relative percentage contents and characteristic ratio values of the fatty acids of samples VIC2, VIC5 and VIC7

\begin{tabular}{|c|c|c|c|c|c|c|c|c|c|c|c|c|c|c|}
\hline \multirow[t]{2}{*}{ Sample } & \multicolumn{11}{|c|}{ Amino acidic relative percentage content } & \multirow[t]{2}{*}{$A / P$} & \multirow[t]{2}{*}{$\mathrm{P} / \mathrm{S}$} & \multirow[t]{2}{*}{$\Sigma \mathrm{D}(\%$} \\
\hline & Ala & Gly & Val & Leu & Ile & Ser & Pro & Phe & Asp & Glu & Hyp & & & \\
\hline VIC 2 & 8.1 & 21.3 & 5.0 & 9.3 & 4.5 & 8.6 & 2.0 & 3.8 & 18.6 & 18.4 & 0.4 & 1.4 & 1.3 & 48.9 \\
\hline VIC 5 & 15.0 & 32.3 & 4.8 & 6.8 & 2.9 & 7.1 & 11.4 & 2.0 & 10.2 & 1.0 & 6.6 & 0.5 & 1.6 & 23.4 \\
\hline VIC 7 & 12.2 & 21.6 & 4.5 & 6.1 & 3.2 & 4.8 & 10.6 & 3.5 & 9.5 & 12.8 & 11.4 & 6.0 & 1.1 & 79.7 \\
\hline
\end{tabular}




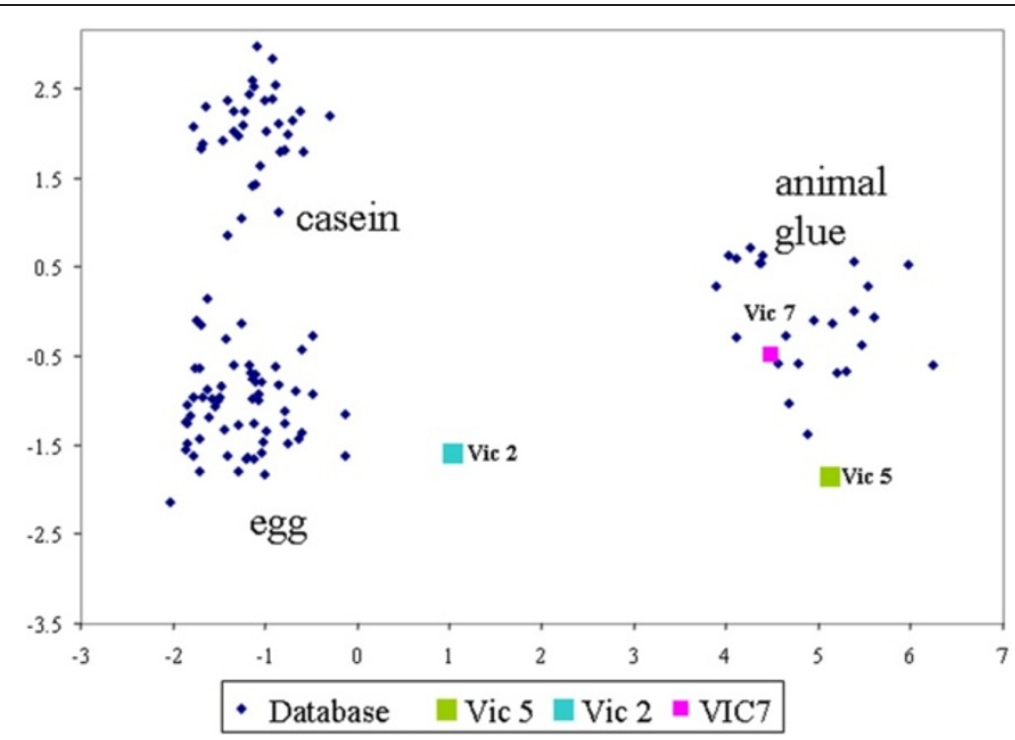

Figure 5 Principal Component analysis score plot of the amino acids percentage relative content in samples VIC2, VIC 5 and VIC7.

resin while butolic acid is indicative of shellac [18,31]. Markers of a well preserved Pinaceae resin such as pimaric acid, sandaracopimaric acid or isopimaric acid were not present in any of the samples. Levoglucosane, pyrolysis product of a glucose containing material, and xylofuranose, characteristic pyrolysis product of natural gums (fruit tree, tragacanth, arabic gums or their mixtures) [5], have been found, suggesting the presence of a mixture of polysaccharide materials.

- VIC 5 sample presents a pyrogram characterized by relatively high amounts of monocarboxylic acids, being palmitic and stearic acids the most abundant, and low amounts of dicarboxylic acids. This profile suggests the presence of a siccative oil together with a non drying

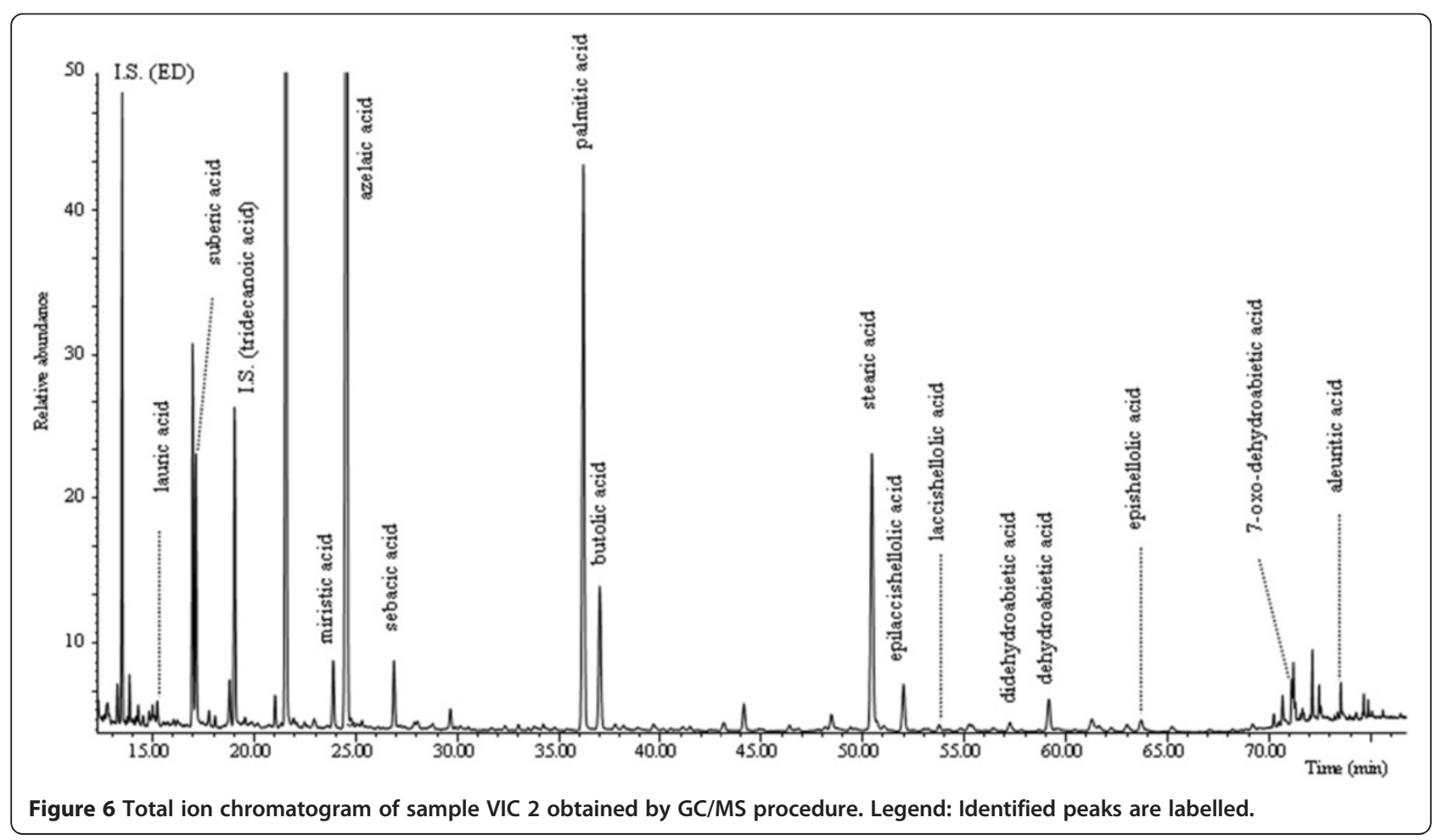



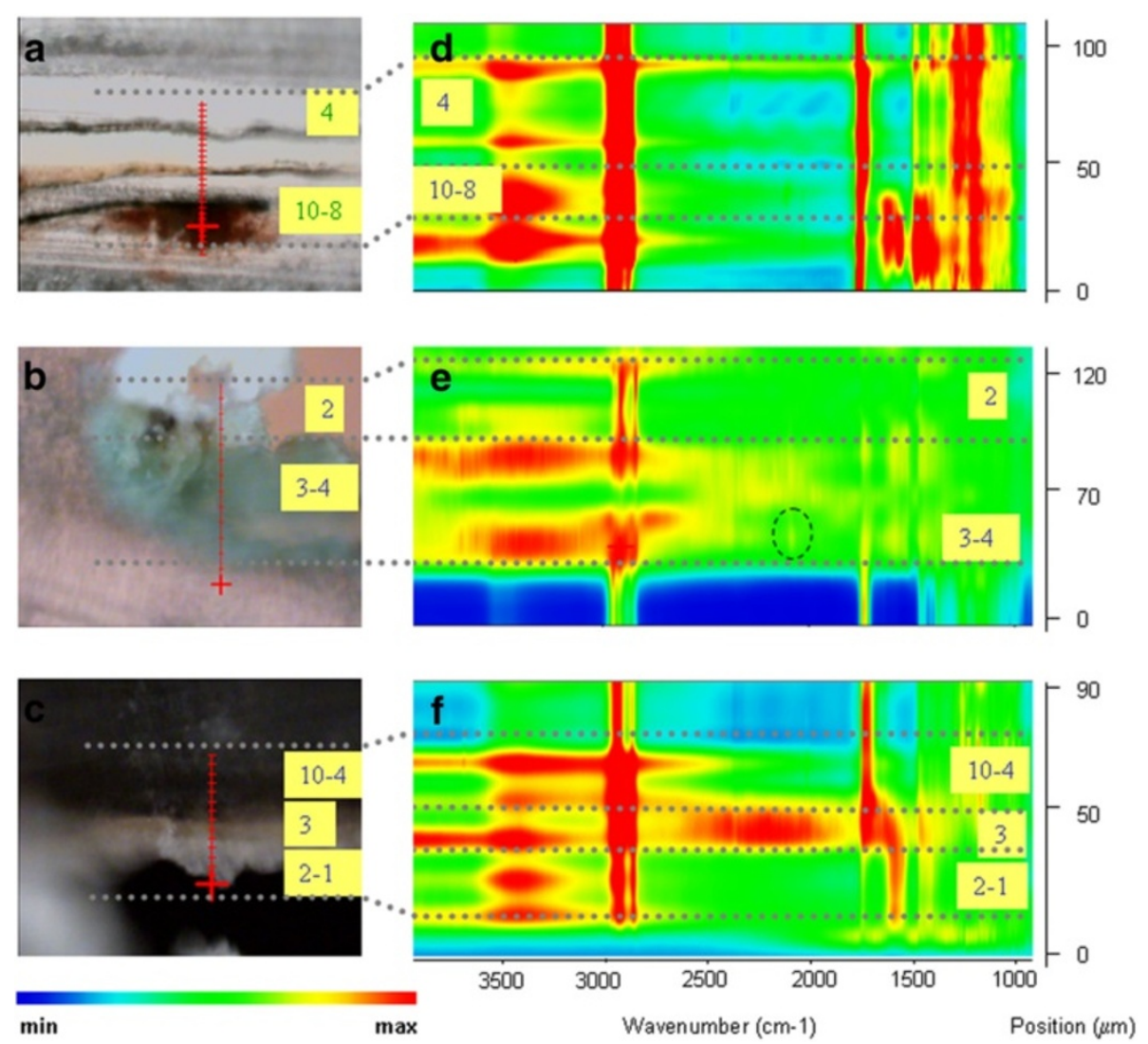

Figure 7 Photomicrograph of the microtomed cross-sections. a) VIC $2(12 \mu \mathrm{m})$; b) VIC $5(4 \mu \mathrm{m})$; c) VIC $7(12 \mu \mathrm{m})$; line scan of d) VIC 2; e) VIC 5; f) VIC 7. The red line marks the line selected to perform the line scan. Squared numbers indicate the layers from the cross-section of the sample. Grey dotted lines indicated the position (in both the linescan and the stratigraphy) in which spectra features change.

lipid material. This non drying fat has been identified as egg on the basis of the presence of traces of hexadecanonitrile and octadecanonitrile (markers of egg) in the pyrogram. Markers of both plant and animal resins were absent. The markers of polysaccharide materials in sample VIC 5 presented a similar profile to samples VIC 27 , indicating that also in this case a mixture of polysaccharide binders is present [5].

\section{Gas chromatography/mass spectrometry}

The analysis of the amino acidic fraction by GC/MS shows the presence of hydroxyproline, marker of collagen, in all three samples. The amino acid relative percentage contents of the painting samples (reported in Table 6) was subjected to a multivariate statistical analysis together with a data set of 121 reference samples of animal glue, egg and casein, using the principal components analysis (PCA) method [32] .

The PCA score plot (Figure 5) shows that VIC 7 and VIC 5 are located in the animal glue cluster or close to it. However, VIC 5 shows a percentage content of glutammic acid (Table 6) quite low for animal glue, this might be the result of a bacterial attack of the painting
[33,34]. This ascertained degradation process does not allow us to exclude that another proteinaceous materials was simultaneously present. The presence of, hexadecanonitrile, marker of egg, in the pyrogram of this sample, allows to conclude that both egg and animal glue are present in VIC 5. VIC 2 contains both egg and animal glue, as it can be assessed from its position in the PCA score plot [5].

The most abundant peaks in all chromatogram of the lipidic fraction (presented in Figure 6) are palmitic, stearic, suberic, azelaic, and sebacic acids. The calculated characteristic parameters for these acids [1] are reported in Table 6.

The A/P ratio for samples VIC 2 and VIC 7 clearly points out to a drying oil. As the $\mathrm{A} / \mathrm{P}$ and $\mathrm{P} / \mathrm{S}$ ratios obtained for sample VIC 2 are perfectly in agreement with those of a reference linseed oil, it can be concluded that egg, which was detected by the analysis of the proteinaceous fraction, is a minor component For VIC 5, the $\mathrm{A} / \mathrm{P}$ ratio lower than 1 seems to point to a mixture of a drying oil (attested by a consistent amount of dicarboxylic acids) with a non drying fat. The presence of egg has been already evidenced by pyrolisis (see above). 

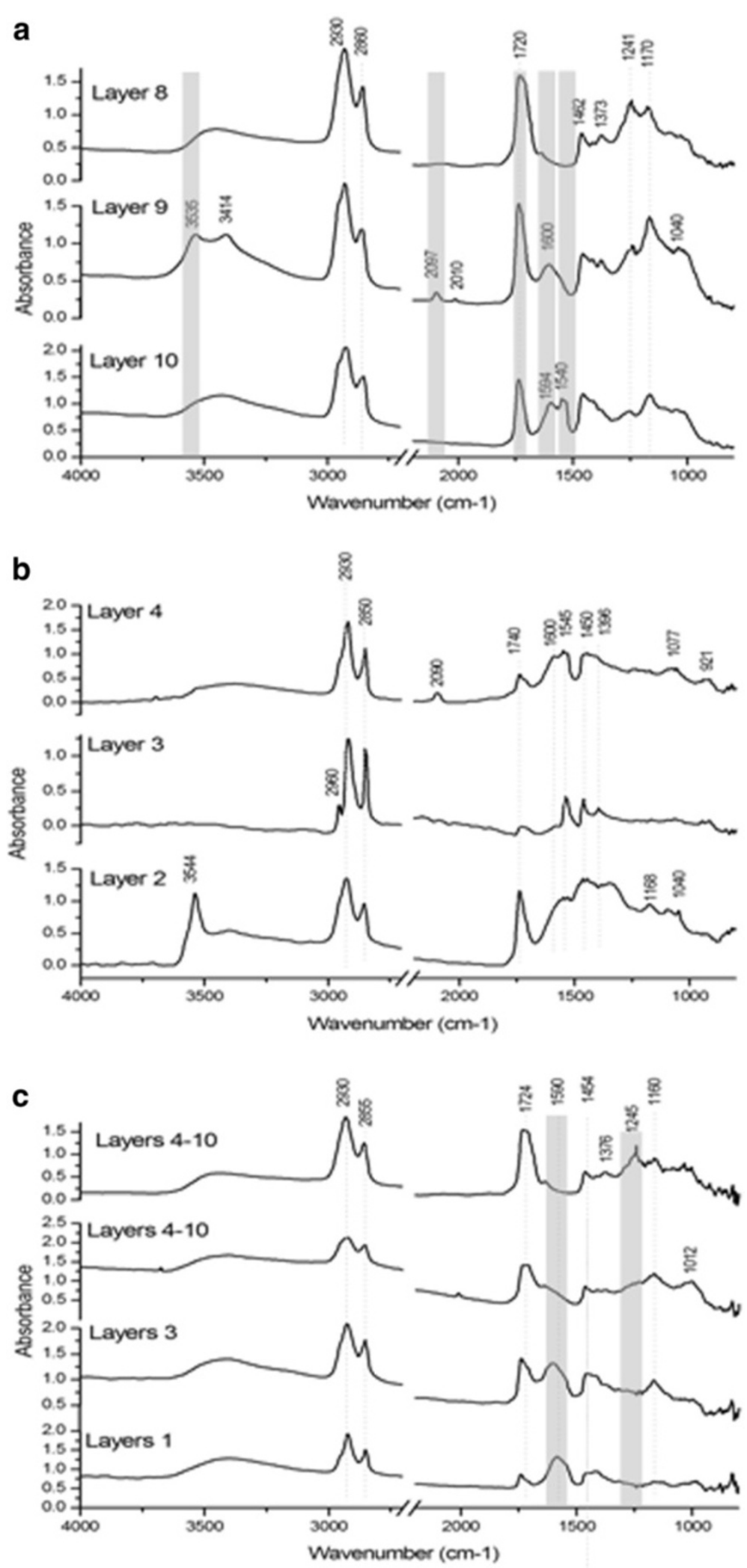

Figure 8 Characteristic SR FTIR spectra of some layers of the samples a) VIC 2; b) VIC 5; c) VIC 7. Spectra have been recorded with a $8 \times 8$ $\mu \mathrm{m}^{2}$ aperture, 50 scans, $4 \mu \mathrm{m}$ step and $8 \mathrm{~cm}^{-1}$ resolution. The bands chosen for the mapping are highlighted in grey. 
Table 7 Summary of the information obtained from the linescan and the spectra

\begin{tabular}{|c|c|c|c|c|c|c|}
\hline Sample & Layer & $\begin{array}{c}\text { Linescan } \\
\text { position }(\mu \mathrm{m})\end{array}$ & $\begin{array}{l}\text { Linescan main } \\
\text { features }\left(\mathrm{cm}^{-1}\right)\end{array}$ & Other bands in the spectra $\left(\mathrm{cm}^{-1}\right)$ & $\begin{array}{l}\text { Material identified } \\
\text { from the spectra }\end{array}$ & $\begin{array}{c}\text { Mapped } \\
\text { bands }\left(\mathrm{cm}^{-1}\right)\end{array}$ \\
\hline \multirow[t]{4}{*}{ VIC 2} & $10-9$ & $10-45$ & $\begin{array}{c}1590 \\
1530 \\
1410(\mathrm{ba}) \\
1167\end{array}$ & $\begin{array}{c}2930,2850,1730,1590 \\
1530,1462,1415,1387 \\
1240,1167,1040\end{array}$ & Oil & $\begin{array}{l}1590 \\
1540\end{array}$ \\
\hline & 9 & $40-45$ & - & 2012 & Bone black & - \\
\hline & & & - & 2092 & Prussian blue & 2092 \\
\hline & $8-4$ & $50-100$ & $\begin{array}{l}1710 \\
1260 \\
1160\end{array}$ & $\begin{array}{c}2930,2850,1720,1450 \\
1373,1260,1160\end{array}$ & Resin & 1715 \\
\hline \multirow[t]{3}{*}{ VIC 5} & $3-4$ & $30-90$ & - & $\begin{array}{c}\text { 2930, 2850, 1730, } \\
1580,1540,1460,1415\end{array}$ & Oil & - \\
\hline & 4 & $30-45$ & 2090 & 2090 & Prussian blue & - \\
\hline & & & - & $3699,3620,1100,1050$ & Clay (kaolinite) & - \\
\hline \multirow[t]{5}{*}{ VIC 7} & $1-2$ & $0-30$ & 1580 & $\begin{array}{c}2930,2855,1730,1590 \\
1460,1380\end{array}$ & Oil & 1580 \\
\hline & 3 & $30-45$ & 1580-1730 (broad area) & $\begin{array}{c}2930,2855,1730,1590 \\
1460,1387,1160\end{array}$ & Oil & - \\
\hline & $4-10$ & $45-65$ & - & 3535,1410 & Lead white & - \\
\hline & & & - & 2012 & Bone black & - \\
\hline & & & 1730 & $\begin{array}{l}2930,2855,1720,1632 \\
1460,1376,1245,1160\end{array}$ & Resin & 1250 \\
\hline
\end{tabular}

Finally, in the acidic fraction of VIC 2 and VIC 7 the presence of the molecular markers of a Pinaceae resin (dehydroabietic acid together with didehydroabietic and 7-oxo dehydroabietic acid) and shellac (butolic, aleuritic, epishellolic, shellolic, laccishellolic, epilaccishellolic acids) were individuated [6,32,35-37].

\section{Synchrotron radiation micro FTIR}

A critical point in performing SR FTIR mappings in transmission mode is the sample preparation as it is necessary to obtain very thin sample sections to avoid the complete absorption of the transmitted beam. Microtoming after embedding the sample in a epoxy resin usually causes several problems such as infiltration of the resin and crumbling and lost of particles [3,4]. Notwithstanding this, an epoxy resin worked particularly well with VIC samples given their high content in organic materials, resulting in flexible intact cross sections, which did not show any contamination of the embedding resin and were easy to cut.

A photomicrograph of each cross-section of the samples after microtoming is shown in Figure 7 (a, b, c). The thin section of VIC 2 contained only superficial layers (10 to 4$)$.

The linescan permits to easily visualise the distribution of the main functional groups in the spectra along the line depicted in the photomicrograph of the sample (Figure 7 a,b,c). The linescan, being a representation of the spectra acquired at a sequence of points (wavenumbers vs position), permits to visualise the main spectral features (red color) of the different layers. The features highlighted in the linescans, mainly correspond to $\mathrm{CH}$ st (2800-3000 $\left.\mathrm{cm}^{-1}\right)$, carbonyl bands $\left(1650-1750 \mathrm{~cm}^{-1}\right)$, CO st $\left(1175 \mathrm{~cm}^{-1}\right.$ for oils and $1260 \mathrm{~cm}^{-1}$ for resins) and metal carboxylates bands (1600-1500 $\left.\mathrm{cm}^{-1}\right)$. In Figure 8, some representative SR FTIR spectra of each sample are presented.

In Table 7 the main spectral features (wavenumbers), highlighted by the linescan (red color) along the crosssection, are summarized. In this Table the linescan position between which those features are present is indicated and this information is related to the layer in the cross-section. The organic material identified in the spectra are also specified.

By mapping the bands specified in Table 7 the distribution of some of the organic materials could be achieved for VIC 2 and VIC 7. This was not possible for sample VIC 5 due to irregularities in the width of the slice. False color maps are shown in Figures 9 and 10 for VIC 2 and VIC 7, respectively, and represent the distribution of specific functional group (color is a function of the peak height versus position) in the cross-section. Mappings resulted from the accurate study of individual spectra to assure that the highlighted areas were consistent with the material localization.

SR micro FTIR mapping of the organic materials identified by GC/MS highlights the alternate use of oil, used as binding medium of the thin pigment layers, and resin 

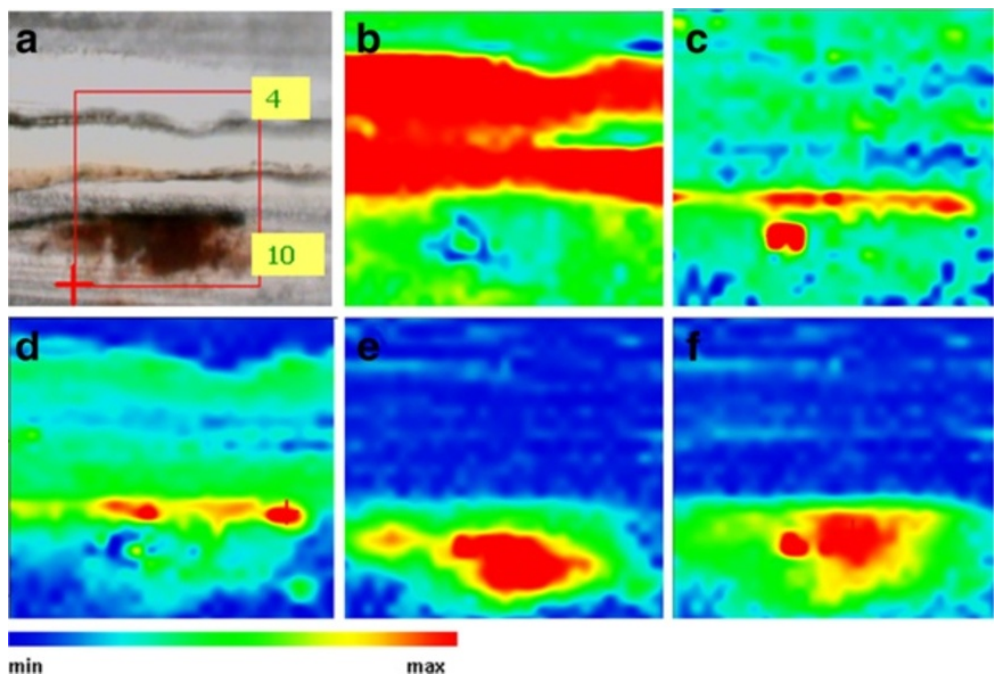

$\min$

Figure 9 a) Photomicrograph of the microtomed cross-section of VIC $\mathbf{2}$ (width: $12 \mu \mathrm{m}$ ). The rectangle marks the area selected to perform the SR FTIR mapping; chemical image of b) 1717 , c) 2090 , d) 3539 , e) 1590 and f) $1533 \mathrm{~cm}^{-1}$. Mapped area $102 \times 174 \mu \mathrm{m}$.

layers. By mapping the bands at 1715 and $1260 \mathrm{~cm}^{-1}$, considered as characteristic of a terpenoid resin, wide areas presenting the maximum intensities are coincident with the non pigmented layers on top of the stratigraphies. By mapping the carboxylate peaks (1600$1540 \mathrm{~cm}^{-1}$ ), the presence of the saponified oil in the pigmented layers is also established. Finally, mapping of the bands at $2092 \mathrm{~cm}^{-1}$ and $3535 \mathrm{~cm}^{-1}$ allowed establishing the distribution of Prussian blue in layer 8 and zinc white in layers 10 to 8 in VIC 2.

\section{Synchrotron radiation XRD}

Sample VIC 7 was prepared for micro XRD experiments in transmission mode performing line scan measurements

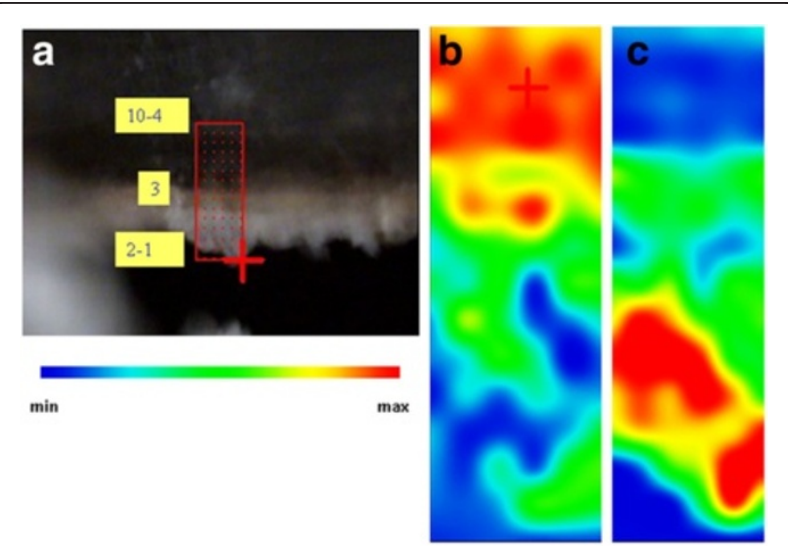

Figure 10 a) Photomicrograph of the microtomed cross-section of VIC $7(12 \mu \mathrm{m})$. chemical images of b) $1250 \mathrm{~cm}^{-1}$ and c) $1590 \mathrm{~cm}^{-1}$. Mapped area is $131 \times 48 \mu \mathrm{m}$. The rectangle in a) marks the area selected to perform the SR FTIR mapping. across the sample cross-sections. Figure 11 shows the $2 \theta$ diffraction peaks in respect to vertical position on the chromatic layers: the alternation of organic (non diffracting amorphous layers corresponding to the white areas) and crystalline phases (with the high intensity diffraction peaks corresponding to the grey and black areas) is easily appreciated. The line scan is acquired in the area of the cross section evidenced by a red line in the cross section image reported in Figure 11a. XRD patterns from the most characteristic chromatic layers are also presented (Figure 11c).

It is important to specify that the pattern matching process presented some difficulties due to the nature of the samples: painting cross-sections are formed by a mixture of different crystals of different size and orientation that are not powdered to obtain a statistically arranged mixture of crystals, all the more so when analyzed with a micrometric beam. Samples are not, thus, presenting all possible orientation under the excitation rays. Though some crystals are small enough to be considered randomly oriented, big crystals such as cerussite and hydrocerussite are bigger than the beam spot used obtaining a diffraction pattern different from that of the standards and thus difficult to be identified. However, SR XRD permitted the unequivocal characterization and layer location of most of the pigments and dryers (barite $\left(\mathrm{BaSO}_{4}\right)$, hydroxyapatite $\left(\mathrm{Ca}_{5}\left(\mathrm{PO}_{4}\right)_{3} \mathrm{OH}\right)$, cerussite $\left(\mathrm{PbCO}_{3}\right)$, hydrocerussite $\left(\mathrm{Pb}_{3}\left(\mathrm{CO}_{3}\right)_{2}(\mathrm{OH})_{2}\right)$, crocoite $\left.\left(\mathrm{PbCrO}_{4}\right)\right)$ present (Table 3). It is interesting to note the identification of lead acetate $\left(\mathrm{Pb}\left(\mathrm{C}_{2} \mathrm{H}_{3} \mathrm{O}_{2}\right)_{2} \cdot 3 \mathrm{H}_{2} \mathrm{O}\right)$, a dryer for oil paints, in sample VIC 7 [38]. To the best of our knowledge this is the first experimental evidence of the use of lead acetate as dryer in painting samples. 

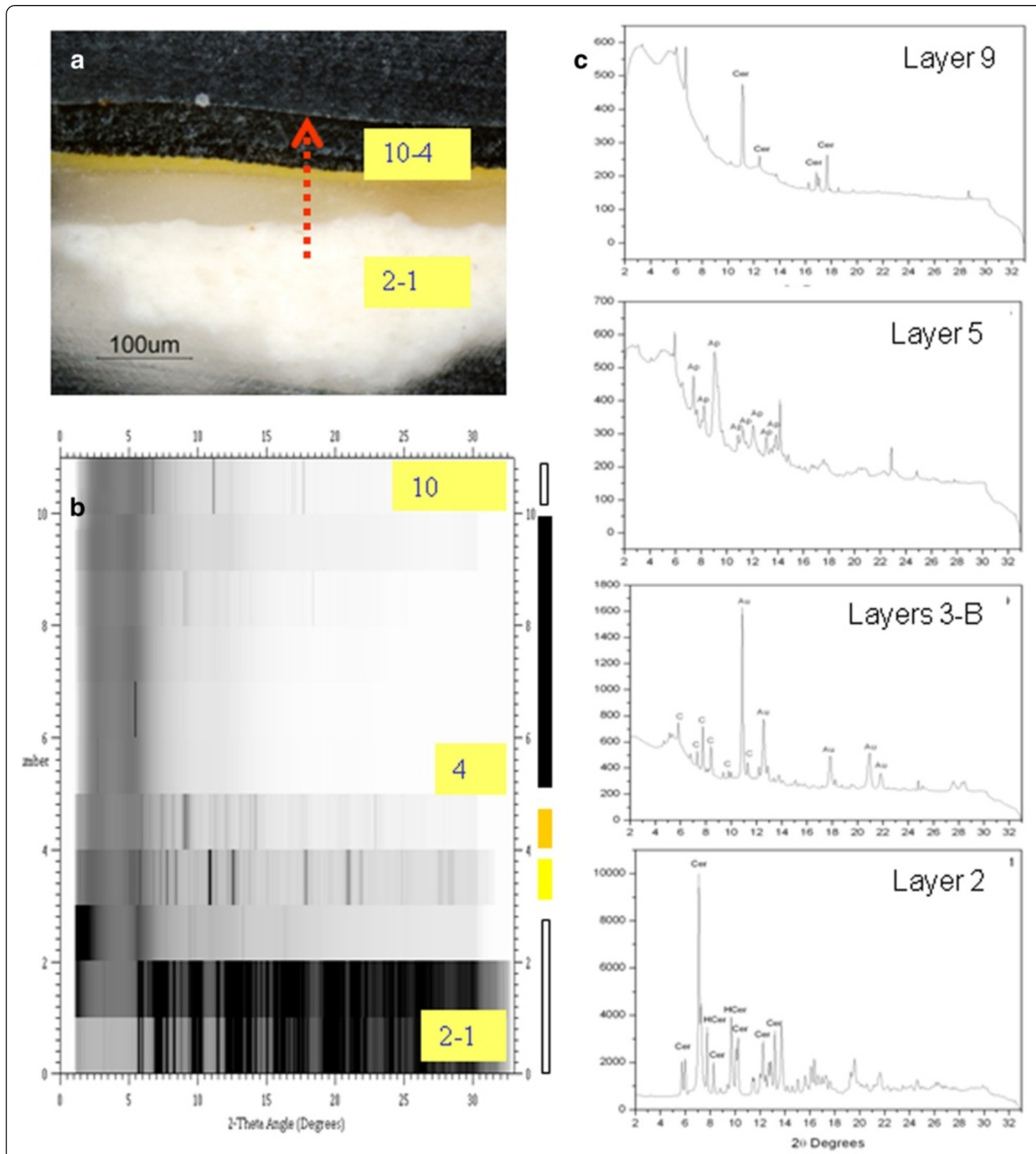

Figure 11 a) polished cross-section prepared for XRD analysis (the arrow indicated the linescan position and its direction) b) XRD linescan from 0 (corresponding to layer 1-2) to 13 (corresponding to layer 10); c) XRD patterns of some of the scans corresponding to different layers. Peaks labeled with letters corresponding to: * (cerussite, $\left.\mathrm{PbCO}_{3}\right), \mathrm{Ap}\left(\right.$ Hydroxyapatite, $\mathrm{Ca}_{5}\left(\mathrm{PO}_{4}\right)_{3}(\mathrm{OH})$ ), $\mathrm{Au}(\mathrm{gold}), \mathrm{C}(\mathrm{crocoite}$, $\mathrm{PbCrO}_{4}$ ) and $\mathrm{HCer}$ (hydrocerussite, $\left.\mathrm{Pb}_{3}\left(\mathrm{CO}_{3}\right)_{2}(\mathrm{OH})_{2}\right)$.

\section{Discussion}

The multi analytical approach used allowed us to gain many pieces of information about the samples and the combined interpretation of the data obtained with different techniques permitted the characterization of the samples layer by layer. Table 8 reports the organic materials characterised as well as their distribution in relation with inorganic ones (from Table 3). 
Table 8 Materials identified with the different techniques

\begin{tabular}{|c|c|c|c|c|c|c|c|}
\hline Sample & $\begin{array}{l}\text { Layer } \\
\text { number }\end{array}$ & FTIR & $\mathrm{Py} / \mathrm{GC} / \mathrm{MS}$ & GC/MS & SR FTIR & $\begin{array}{l}\text { Organic compound } \\
\text { identified }\end{array}$ & $\begin{array}{l}\text { Inorganic materials } \\
\text { (from table 3) }\end{array}$ \\
\hline \multirow[t]{13}{*}{ VIC 2} & 10 & \multirow[t]{6}{*}{$\begin{array}{l}\text { Natural resin } \\
\text { Lipid material }\end{array}$} & \multirow[t]{13}{*}{$\begin{array}{c}\text { Drying oil } \\
\text { Pinaceae resin } \\
\text { Shellac } \\
\text { Polysaccaridic material }\end{array}$} & \multirow[t]{13}{*}{$\begin{array}{c}\text { Linseed oil } \\
\text { Pinaceae resin } \\
\text { Shellac } \\
\text { Egg } \\
\text { Animal glue }\end{array}$} & Lipid material & Linseed oil & $\begin{array}{c}\text { Iron oxide } \\
\text { Calcite } \\
\text { Zinc compound } \\
\text { Calcium oxalates } \\
\text { Quartz }\end{array}$ \\
\hline & 9 & & & & Lipid material & Linseed oil & $\begin{array}{l}\text { Bone black } \\
\text { Prussian blue }\end{array}$ \\
\hline & 8 & & & & Natural Resin & Shellac, pine resin & - \\
\hline & 7 & & & & Natural Resin & Shellac, pine resin & - \\
\hline & 6 & & & & & & \\
\hline & 5 & & & & & & \\
\hline & $A$ & - & & & - & & Gold leave \\
\hline & 4 & - & & & Natural Resin & Shellac,pine resin & \\
\hline & $B$ & & & & - & - & Brass leave \\
\hline & 3 & \multirow[t]{4}{*}{ Lipid material } & & & Lipid material & Linseed oil & \multirow{2}{*}{$\begin{array}{l}\text { Barium sulphate } \\
\text { Lead chrome yellow }\end{array}$} \\
\hline & 2 & & & & Lipid material & Linseed oil & \\
\hline & 1 & & & & Lipid material & Linseed oil & $\begin{array}{l}\text { Clay? } \\
\text { Iron oxide? }\end{array}$ \\
\hline & $C$ & & & & - & - & Brass leave \\
\hline \multirow[t]{4}{*}{ VIC 5} & 4 & \multirow[t]{2}{*}{ Lipid material } & \multirow{4}{*}{$\begin{array}{c}\text { Drying oil } \\
\text { Polysaccharidic material } \\
\text { Egg (traces) }\end{array}$} & \multirow{4}{*}{$\begin{array}{c}\text { Drying oil } \\
\text { Non drying fat (egg?) } \\
\text { Animal glue }\end{array}$} & Lipid material & Linseed oil, egg & \multirow{2}{*}{$\begin{array}{c}\text { Strontium yellow } \\
\text { Prussian blue } \\
\text { Lead white } \\
\text { Kaolinitezinc compound }\end{array}$} \\
\hline & 3 & & & & Lipid material & Linseed oil, egg & \\
\hline & 2 & Lipid material & & & Lipid material & Linseed oil & Lead white \\
\hline & 1 & Polysaccharide material & & & & $\begin{array}{c}\text { Mixture of } \\
\text { polysaccharide } \\
\text { materials }\end{array}$ & \\
\hline \multirow[t]{11}{*}{ VIC 7} & 10 & \multirow{7}{*}{$\begin{array}{c}\text { Natural resin } \\
\text {-Polysaccharide material }\end{array}$} & \multirow{11}{*}{$\begin{array}{c}\text { Drying oil } \\
\text { Pinaceae resin } \\
\text { Shellac } \\
\text { Polysaccharidic material }\end{array}$} & \multirow{11}{*}{$\begin{array}{l}\text { Prepolymerized linseed oil } \\
\text { Pine resin } \\
\text { Shellac } \\
\text { Animal glue }\end{array}$} & Resin & Shellac & \\
\hline & 9 & & & & - & - & $\begin{array}{l}\text { Bone black } \\
\text { Prussian blue }\end{array}$ \\
\hline & 8 & & & & Resin & Shellac, pine resin & \\
\hline & 7 & & & & - & - & - \\
\hline & 6 & & & & resin & Shellac, pine resin & \\
\hline & 5 & & & & $\begin{array}{c}\text { Proteinaceous } \\
\text { material }\end{array}$ & Animal glue & Bone black \\
\hline & 4 & & & & Resin & & \\
\hline & $A$ & & & & - & - & $\begin{array}{l}\text { Chrome yellow } \\
\text { Gold }\end{array}$ \\
\hline & 3 & Lipid material & & & Lipid material & Linseed oil & $\begin{array}{l}\text { Lead white } \\
\text { Zinc white }\end{array}$ \\
\hline & 2 & \multirow[t]{2}{*}{ Lipid material } & & & Lipid material & Linseed oil & Zinc white \\
\hline & 1 & & & & Lipid material & Linseed oil & $\begin{array}{l}\text { Lead white } \\
\text { Lead acetate }\end{array}$ \\
\hline
\end{tabular}

Pigments identified (see also Additional file 1) are mainly of natural origin (such as green earth, calcite or bone black) though some synthetic materials from the end of the $19^{\text {th }}$ century such as chrome green or strontium yellow were also used by the painter. In sample VIC 5, "green cinnabar", a mixture of Strontium yellow and Prussian blue has been used. Lead white has been used in the preparation layers of samples VIC 5 and VIC 7.

A wide variety of metallic leaves have been used, some of them unusual: not only gold and silver ones but also alloys of $\mathrm{Ag} / \mathrm{Au}$ and $\mathrm{Cu} / \mathrm{Zn}$ or $\mathrm{Al} / \mathrm{Pd}$ (see Additional file 1) depending on the in-depth in the sample of those metallic leaves and the effect to be produced. 
As far as the organic materials are concerned, a drying oil has been used as binding medium in pigment layers as well as in the mordants of the metallic leaves, while proteinaceous materials (egg and animal glue) were mainly used for canvas preparation layers. In some particular samples, proteinaceous materials were also used as binding media of pigment layers (such as VIC 5 and VIC 7). Polysaccharide materials were identified in all samples and localised in sample VIC 5 on the canvas preparation layer. Finally, natural resins (identified as shellac and a Pinaceae resin) were mainly localised in the superficial layers.

Metallic leaves have been applied in two different ways: on a linseed oil mordant or on a shellac layer. Moreover, different kinds of mordants have been also applied depending on the kind of metallic leaves and disposition in the stratigraphy. This way, VIC 2 and VIC 7 present a mordant made of linseed oil (used in paintings of big size due to its capacity of remain adherent for a long time) while other samples (results presented as Additional file 1) present linseed oil in mixture with lead white and Prussian blue, or a zinc containing material compounds (probably zinc white).

It is also of particular interest the widespread use of shellac (mixed with pine resin) to generate a high number of thin layers on top of the stratigraphy of VIC 2 and 7. Those layers alternated with pigment layers and metallic leaves generate the shiny silvery or gilded effect characteristic of the later painting technique of Josep Maria Sert. The fact that shellac was probably refined to painting purposes by using sodium hypochlorite explains the high concentrations of $\mathrm{Cl}$ (by EDS) in the shellac layers (Table 3). The mapping of $\mathrm{Cl}$ in the SEM polished cross-sections (results not shown) in fact was coincident with the non pigmented layers on top of the stratigraphy of those samples.

\section{Conclusions}

The combined use of different techniques applied on different aliquots of the same sample, and the complementary interpretation of the results obtained, allowed us to establish the build-up of each sample, the materials used and, thus, to ascertain the painting technique of Josep Maria Sert in his paintings in the city of Vic and to appreciate his technical evolution. In particular synchrotron experiments gave the final answer to key questions allowing us to establish not ony the organic media distribution but also the presence of some pigments as well as the distribution of ageing products such as oxalates and carboxylates.

Josep Maria Sert works present two kinds of painting techniques. One is a traditional technique based on the application of one or few pigmented layers on a preparation, using mainly linseed oil as binding medium. The other technique is based on the application of several thin layers, mainly organic, with some thin pigmented layers and metallic leaves in the between. This study allowed to establish that Sert started using the first traditional technique, subsequently moving to the use of both techniques at the same time (painting "The four seasons" from 1917-1920) to finally use exclusively the complex multilayered painting technique in the last stage of his career. These experimental evidences correspond to the two different finishing described from art historians for Sert paintings: a polychrome and decorative mural painting and a monochrome painting (sepia, gilded and silvery tonalities) that was, in the end, assumed as his characteristic way of painting [17].

\section{Additional file}

Additional file 1: Table S1. Summary of the morphological characterization of the samples. Table S2. FTIR and Py/GC/MS results for the 4 paint samples. Information on the layers is given when possible.

\section{Abbreviations}

SEM-EDS: Scanning electron microscopy - Electron Dispersive Spectroscopy; SR $\mu$ XRD: Synchrotron Radiation micro X-Ray Diffraction; $\mu$ FTIR: micro Fourier Transform Infrared Spectroscopy; GC/MS: Gas Chromatography/Mass Spectrometry; PY/GC/MS: Pyrolisis/Gas Chromatography/Mass Spectrometry; PCA: Principal Component Analysis; HPLC: High Performance Liquid Chromatograpy; HMDS: Hexamethyldisilazane; MTBSTFA: N-tertButyldimethylsilyl-N-methyltrifluoroacetamide; IS: Internal Standard; ED: Hexadecane.

\section{Competing interest}

The authors declare that they do not have competing interests.

\section{Authors' contributions}

All authors contributed to data analyses and to finalizing the manuscript. All authors have read and approved the final version.

\section{Authors' information}

Anna Lluveras-Tenorio majored in Chemical Science at the University of Barcelona (UB), Spain, in 2003. She worked as a research staff member at the University of Barcelona from 2003 until 2005. She obtained her PhD in July 2009 at the University of Barcelona. she currently holds a post-Doc Marie Curie position at the University of Pisa. Her research lines are the

fundamental study of the organic materials used as binders as well as the development of analytical methodologies for painting analysis using GC-MS, FTIR, thermo gravimetric and synchrotron radiation based techniques. Alessia Andreotti graduated in Chemistry in 2002 at the University of Pisa with a thesis on laser cleaning applied to the restoration of paintings. Since 2004, she has been working as a technician at the Department of Chemistry and Industrial Chemistry in the technical-scientific and data evaluation areas. Her research focuses on the characterization of natural and synthetic organic materials collected from samples in the field of Cultural Heritage using instrumental analytical techniques such as HPLC, GC/MS, Py-GC/MS, and direct exposure mass spectrometry (DE-MS). She also specializes in using lasers and other state-of-the-art techniques for cleaning of easel paintings, mural paintings, and other artifacts.

llaria Bonaduce is a lecturer and permanent researcher in the Department of Chemistry and Industrial Chemistry at the University of Pisa; she received her Ph.D. in Chemical Science from the University of Pisa, Italy, in 2006. Her research focuses on the characterization of natural and synthetic organic materials used in works of art and the study of how they degrade during aging. Another major research interest is the development of analytical procedures for the identification of organic materials in paint samples, using mass spectrometric techniques, such as GC/MS, Py-GC/MS, and DE-MS. 
Sarah Boularand graduated in Chemistry at the University of ClermontFerrant and she is working in the cultural heritage field since 1999. Her research lines are the analysis of painting materials, both pigments and binders by means of spectroscopic and electron microscopic techniques. Marine Cotte is beamline responsible at the micro-spectroscopy beamline (ID21), at the European Synchrotron Radiation Facility. Her researches are related to the analysis of ancient materials, in particular paintings, using the $X$-ray and a FTIR microscopes available at ID21.

Josep Roqué received a Ph.D. in Geology at the University of Barcelona (Spain) in 2007. He has been a post doctoral research associate at the Microfocus Spectroscopy beamline (118) at the Diamond Light Source (UK) and at the Nanomateriaux Group at the CEMES-CNRS (Toulouse, France). Maria Perla Colombini currently holds the post of Full Professor of Analytical Chemistry in the Department of Chemistry (Faculty of Science) at the University of Pisa. She holds courses on Analytical Chemistry and the Chemistry of Cultural Heritage. She is Director of the Masters Course on "Materials and Diagnostic Techniques in the Cultural Heritage field". Her research work includes developing analytical procedures based on spectroscopic and chromatographic techniques for characterizing micropollutants in the environment and, especially, organic materials and their degradation products in works of art and archaeological objects. She is head of the Chemical Sciences for the Safeguard of Cultural Heritage research group and specializes in the characterization of binders, organic dyes, and resins using chromatographic and mass-spectrometric techniques. Marius Vendrell-Saz received a Ph.D. in Geology from the University of Barcelona (Spain) and is currently Associated Professor of Cristallography at the University of Barcelona. Since 1984 his research has been focused on the study of the materials used in the cultural heritage, from building materials to paintings.

\section{Acknowledgements}

Authors wish to thank AGAUR (Agència de gestió d'Ajuts Universitaris I de recerca) is acknowledged for the research grant (BE00729) that permitted the stage at the University of Pisa. Samples were kindly provided by Vic city council. We also acknowledge the European Synchrotron Radiation Facility for provision of synchrotron radiation facilities as part of the project EC38 and we would like to thank Isabelle Lethard for assistance in using beamline ID18F.

\section{Author details}

'Departament de Cristal.lografia, Mineralogia I Dipòsits Minerals, University of Barcelona, C/Marti i Franquès S/N, 08015 Barcelona Spain. ${ }^{2}$ Dipartimento di Chimica e Chimica Industriale, University of Pisa, Via Risorgimento 35, 56126 Pisa Italy. ${ }^{3}$ European Synchrotron Radiation Facility, 6 rue Jules Horowitz, F38000 Grenoble France. ${ }^{4}$ Centre de Recherche et de Restauration des Musées de France, CNRS UMR171, Palais du Louvre, Porte des Lions, 14 Quai François Mitterrand, F-75001 Paris France. ${ }^{5}$ Science Division, Diamond Light Source Ltd, Harwell Science and Innovation Campus, Oxon OX11 ODE United Kingdom.

Received: 2 February 2012 Accepted: 27 April 2012

Published: 22 May 2012

\section{References}

1. Andreotti A, Bonaduce I, Colombini MP, Modugno F, Ribechini E: Characterisation of natural organic materials in paintings by GC-MS analytical procedures. In In New Trends in Analytical, Environmental and Cultural Heritage Chemistry. Edited by Colombini MP, Tassi L. Kerala Indai: Transworld Research Network; 2008:389-424.

2. Van der Weerd J, Heeren RMA, Boon JJ: Preparation methods and accessories for the infrared spectroscopic analysis of multi-layer paint films. Stud Cons 2004, 49:193-210.

3. Martin de Fonjaudran C, Nevin A, Piqué F, Catre S: Stratigraphic analysis of organic materials in wall painting samples using micro-FTIR attenuated total reflectance and a novel sample preparation technique. Anal Bioanal Chem 2008, 392:77-86.

4. Cotte M, Checroun E, Mazel V, Solé VA, Richardin P, Taniguchi Y, Walter $P$, Susini J: Combination of FTIR and X-rays synchrotron-based micro-imaging techniques for the study of ancient paintings. A practical point of view E-Preservation Sci 2009, 6:1-9.
5. Bonaduce I, Andreotti A: Py-GC/MS of organic paint binders. In In Organic Mass Spectrometry in Art and Archaeology. Edited by Colombini MP, Modugno F. United Kindong: John Wiley \& Sons; 2009:303-326.

6. Andreotti A, Bonaduce I, Colombini MP, Gautier G, Modugno F, Ribechini E: Combined GC/MS Analytical Procedure for the Characterization of Glycerolipid, Waxy, Resinous, and Proteinaceous Materials in a Unique Paint Microsample. Anal Chem 2006, 78:4490-4500.

7. Cotte M, Susini J, Solé VA, Taniguchi Y, Chillida J, Checroun E, Walter P: Applications of synchrotron-based micro-imaging techniques to the chemical analysis of ancient paintings. J Anal At Spectrom 2008, 23:820-828.

8. Dumas P, Jasmin N, Teillaud JL, Miller LM, Beccard B: Imaging capabilities of synchrotron infrared microspectroscopy. Faraday Discuss 2004, 126:289-302.

9. Salvado N, Buti S, Tobin M, Pantos E, Prag A, Pradell T: Advantages of the Use of SR-FT-IR Microspectroscopy: Applications to Cultural Heritage. Anal Chem 2005, 77:3444-3451.

10. Cotte $M$, Walter $P$, Tsoucaris $G$, Dumas P: Studying skin of an Egyptian mummy by infrared microscopy. Vib Spec 2005, 38:159-167.

11. Cotte M, Susini J, Moscato A, Gratziu C, Bertagnin A, Metrich N: Blackening of Pompeian Cinnabar paintings studied by X-ray micro-spectroscopic imaging. Anal Chem 2006, 78:7484-7492.

12. Cotte M, Checroun E, Susini J, Walter P: Micro-analytical study of interactions between oil and lead compounds in paintings. Appl Phys $A$ 2007, 89:841-848.

13. Lluveras A, Boularand S, Roqué J, Cotte M, Martinez-Ruiz G, Giráldez P, Vendrell-Saz M: Weathering of gilding decorations investigated by SR: development and distribution of calcium oxalates in the case of Sant Benet de Bages (Barcelona, Spain). Appl Phys A 2008, 90:23-33.

14. Echard JP, Cotte M, Dooryhee E, Bertrand L: Insights into the varnishes of historical musical instruments using synchrotron micro-analytical methods. Appl Phys A 2008, 92:77-81.

15. Salvado N, Buti S, Nicholson J, Emerich H, Labrador A, Pradell T: Identification of reaction compounds in micrometric layers from gothic paintings using combined SR XRD and SR FTIR. Talanta 2009, 79:419-428.

16. Ylla-Català i Genís M: Josep Maria Sert i la ciutat de Vic.: ; 2006. Editorial Diac.

17. BibUnstructured>Andreotti A, Bonaduce I, Colombini MP, Modugno F, Ribechini E: The diagnosis of the yellowing of the marble high-reliefs and the black decorations in the chapel of the tomb of Saint Anthony (Padua-Italy). J Mass Spect 2009, 284:123-130.

18. Derrick MR, Stulik D, Landry JM: Infrared Spectroscopy in Conservation Science. Los Angeles (USA): The Getty Conservation Institute; 1999.

19. Salvadó N, Pradell T, Pantos E, Papiz MZ, Molera J, Seco M, Vendrell-Saz M: Identification of copper-based green pigments in Jaume Huguet's Gothic altarpieces by Fourier transform infrared microspectroscopy and synchrotron radiation X-ray diffraction J Synchrotron Rad 2002, 9:215-222.

20. Hammersley AP, Svensson O, Hanfland M, Fitch AN, Hausermann D: Twodimensional detector software: From real detector to idealised image or two-theta scan. High Press Res 1996, 14:235-248.

21. Abelev $E$, Sezin N, Ein-Eli Y: An alternative isolation of tungsten tips for a scanning tunneling microscope. Re Sci Instrum 2005, 76:106-105.

22. Meilunas RJ, Bentsen JG, Steinberg A: Analysis of Aged Paint Binders by FTIR Spectroscopy. Stud Conserv 1990, 35:33-51.

23. Derrick MR, Stulik DC, Landry JM, Buffard SP: Infrared mapping microspectroscopy for identification of furniture finish layers. In Wooden Artifacts Group Postprints of the American Society for Conservation: 2-3 June, 1990. Edited by A.I.C. Washington, DC: Richmond, Virginia; 1990.

24. Adrover Gracia I: Applicazioni della spettrofotometria IR allo studio dei beni culturali. In Padova. Edited by Collana I. Italy: Talenti; 2001.

25. Helwig K: The characterization of iron earth pigments using infrared spectroscopy. In In Infrared and Raman User's Group Postprints Canadian Conservation Institute.: ; 1998:83-92.

26. Biakiaris D, Danilia S, Sotiropoulou S, Katsimbiri O, Pavlidou E, Moutsatsou AP, Chryssoulakis Y: Ochre-differentiation through micro-Raman and micro-FTIR spectroscopies: application on wall paintings at meteora and Mount Athos. Greece Spectrochim Acta A 1999, 56:3-18.

27. Bruni S, Cariati F, Casadio F, Toniolo L: Spectrochemical characterization by micro-FTIR spectroscopy of blue pigments in different polychromeworks of art. Vib Spectrosc 1999, 20:15-25.

28. Madejová J: FTIR techniques in clay mineral studies Vib Spectrosc 2003, 31:1-10. 
29. Van der Weerd J: Microspetroscopic analysis of traditional oil paint:: AMOLF; 2002. PhD thesis.

30. Silva CE, Silva LP, Edwards HGM, de Oliveira LFC: Diffuse Reflection FTIR database of dyes and pigments. Anal Bioanal Chem 2006, 386:2183-2191.

31. Colombini MP, Bonaduce I, Gautier G: Molecular Pattern Recognition of Fresh and Aged Shellac. Chromatographia 2004, 56:357-364.

32. Brereton RG: Chemometrics Data Analysis for the Laboratory and Chemical Plant. West Sussex (England): J. Wiley \& Sons Ltd; 2004

33. Donati I: Enzimi, acidi organici ed altri metaboliti coinvolti nella patogenesi di penicillium spp. Università di Bologna (Italy): PhD tesi; 2008.

34. Colombini MP, Andreotti A, Bonaduce I, Modugno F, Ribechini E: Analytical Strategies for Characterizing Organic Paint Media Using Gas Chromatography/Mass Spectrometry. Acc Chem Res 1010, 43:715-727.

35. Colombini MP, Modugno F: Characterisation of proteinaceous binders in artistic paintings by chromatographic techniques J Sep Sci 2004, 27:140-160.

36. Bonaduce I, Colombini MP: The characterization of beeswax in works of art by gas chromatography-mass spectrometry and pyrolysis-gas chromatography-mass spectrometry procedures. J Chromatogr A 2004, 1028:297-306.

37. van den Berg KJ, Boon JJ, Pastorova I, Spetter LFM: Mass spectrometric methodology for the analysis of highly oxidized diterpenoid acids in Old Master paintings. J Mass Spectrom 2000, 35:512-533.

38. Carlyle L: Paint driers discussedin nineteenth-century British oil painting manuals. J Am Inst Conserv 1999, 38:69-82.

\section{Publish with ChemistryCentral and every scientist can read your work free of charge \\ "Open access provides opportunities to our colleagues in other parts of the globe, by allowing anyone to view the content free of charge." \\ W. Jeffery Hurst, The Hershey Company. \\ - available free of charge to the entire scientific community \\ - peer reviewed and published immediately upon acceptance \\ - cited in PubMed and archived on PubMed Central \\ - yours - you keep the copyright \\ Submit your manuscript here: \\ http://www.chemistrycentral.com/manuscript/<smiles>c1ccccc1</smiles> Chemistry Central}

